\title{
THE EFFECT OF A POZZOLANIC BY-PRODUCT CONTAINING GLASS POWDER AND METAKAOLIN ON THE PROPERTIES AND AAR RESISTANCE OF MORTAR INCORPORATING CRUSHED GLASS
}

\author{
"KĘSTUTIS BARKAUSKAS, DŽIGITA NAGROCKIENE் \\ Vilnius Gediminas Technical University, Sauletekio av. 11, Vilnius, LT-10223, Lithuania \\ "E-mail: kestutis.barkauskas@vilniustech.lt
}

Submitted September 29, 2021; accepted November 18, 2021

\begin{abstract}
Keywords: Ground waste glass, Metakaolin, Mortar, Microstructure, AAR
The paper presents the research into the effect of an integrated pozzolanic addition containing glass powder and metakaolin on the physical and mechanical properties and the resistance to an alkali aggregate reaction in mortars incorporating crushed glass. Six batches of specimens were made for the tests. Sand was replaced with $25 \%$ of crushed waste glass in all the specimens. Cement was replaced with $5 \%$ of glass power (GP) and $5 \%-25 \%$ of metakaolin (MK) by weight. Specimens containing $20 \%$ of the compound pozzolanic addition were found to have better physical and mechanical properties and higher resistance to alkali aggregate reactions compared to the reference specimens without the addition. Additional hydration products were observed in X-ray and microstructure tests. The formation of new products confirms the results of the tests of the physical and mechanical properties and resistance to alkali aggregate reactions. Mortars incorporating crushed glass were found to be suitable for applications in potentially corrosive environments when modified with a $20 \%$ of a compound pozzolanic addition consisting of $5 \%$ waste glass powder and $15 \%$ waste metakaolin.
\end{abstract}

\section{INTRODUCTION}

Concrete is the most popular construction material used in the majority of construction work in the world. According to different standards, the normative lifetime of building structures ranges from 50 to 70 years and the service life of reinforced concrete structures varies depending on the type and purpose of the structure. Portland cement (PC) is the major ingredient of concrete. Unfortunately, manufacturing Portland cement generates very high $\mathrm{CO}_{2}$ emissions accounting for around $7 \%$ of the total global $\mathrm{CO}_{2}$ emission per annum [1]. Therefore, the concrete industry currently faces major challenges in finding cost-effective strategies in reducing the carbon dioxide emissions from manufacturing Portland cement [2]. Using mineral materials reclaimed from industrial waste to replace cement and natural aggregates is one of the most common environmental impact abatement techniques in the concrete industry [3-8]. Different alternatives, such as crushed glass, glass powder and metakaolin, are considered to be viable solutions for a greener and more sustainable civil construction industry as these secondary raw materials are readily available [9-11]. Besides, the amount of waste glass accumulated raises concerns about its disposal. Only a small portion of glass waste is currently recycled and reused [12-13].
However, a much bigger share (about $70 \%$ ) is disposed in landfills [14-15]. A scientific literature review has shown that glass powder acts as a pozzolanic material in concrete, i.e., by reacting with portlandite it forms an additional C-S-H phase [16]. On the other hand, almost any other inorganic mineral that does not form a negative reaction with $\mathrm{PC}$ can be classified as a micro-aggregate. Metakaolin is another type of industrial waste generated in manufacturing processes and accumulated in storage places. The annual generation of metakaolin in Lithuania is almost 1000 tonnes. Metakaolin is obtained via an endothermic reaction of kaolin. The dehydroxylation of kaolin starts at $450{ }^{\circ} \mathrm{C}$ and continues at a temperature up to $900{ }^{\circ} \mathrm{C}$; amorphous metakaolin $\mathrm{Al}_{2} \mathrm{Si}_{2} \mathrm{O}_{7}$ is obtained at a temperature above $925-950{ }^{\circ} \mathrm{C}$; at $1050{ }^{\circ} \mathrm{C}$ metakaolin transforms into spinel $\mathrm{Si}_{3} \mathrm{Al}_{4} \mathrm{O}_{12}$ and mullite [7]. In terms of reactivity, metakaolin is one of the most effective pozzolans with reactivity of $954 \mathrm{mg} \mathrm{Ca}(\mathrm{OH})_{2} / \mathrm{g}$ compared to $427 \mathrm{~g}$ reactivity of silica microspheres and $875 \mathrm{~g}$ of fly ash [17]. However, incorporation of metakaolin into the mix may reduce the workability of standard concrete. Compared to the addition of silica fume, concrete mixes modified with metakaolin require $25 \%-35 \%$ less superplasticisers [18].

Radonjanin et al. replaced $10 \%$ of ordinary Portland cement by metakaolin and found that the early strength 
of the modified concrete was the same as the strength of the reference concrete, but after 28 days, the compressive strength of the modified concrete increased by $13 \%$ and by an additional $9 \%$ after 90 days [19].

Ouyang et al. found that the optimal level for replacing cement with metakaolin was $15 \%$, leading to a $20 \%$ improvement in the compressive strength; however, superplasticisers must be added in order to ensure the workability of the modified concrete [20]. Metakaolin has an effect on the structure of concrete pores by reducing the transmission of corrosive ions and the rate of diffusion [21]. Such a modification can increase the durability of concrete. A lower $\mathrm{Cl}$ concentration in the pore solution was found in cement pastes containing $10 \%$ and $20 \%$ of metakaolin. Metakaolin incorporated in concrete mixes reduces the expansion of concrete in sodium hydroxide solutions as well as the expansion caused by an alkali aggregate reaction [22-24]. Metakaolin was also found to be an alternative pozzolanic addition and an effective replacement of silica fume in high performance concrete [25]. The study presented, in this paper, focuses on the partial replacement of cement with metakaolin in a mortar incorporating crushed glass.

Crushed glass in cement mortars can induce an alkali aggregate reaction (AAR). AAR occurs in concretes containing crushed glass with particles bigger than $0.5 \mathrm{~mm}$. However, a glass powder with a particle size less than $300 \mu \mathrm{m}$ has a pozzolanic effect and, thus, can reduce the expansion caused by the alkali silica reaction (ASR) [10].

Rajabipour et al. explain that bigger particles of crushed sand (in the range of a small particle size) have sufficiently wide microcracks for hydroxyl ions to diffuse, leading to high concentrations of dissolved silica dioxide and sodium. This high concentration creates favourable conditions for the formation of ASRs [26].
On the other hand, the volume of the gel in the $\mathrm{C}-\mathrm{S}-\mathrm{H}$ gel/cement grain interface is not large due to the unlimited content of silica dioxide and sodium hydroxide. In contrast to the processes taking place in bigger particles, the internal AARs in smaller particles (e.g., a powder) is very low and the inter-phase pozzolanic reaction prevails.

Some authors researched the effect of aggregates on AARs and proposed theories explaining the decreased AAR extent caused by reactive natural aggregates. These theories were taken as a basis for the research presented in the paper. The lower amount of cement used directly reduces the level of alkaline ions and, thus, inhibits the development of AARs [27]. Finely ground reactive silica dioxide adds to the distribution of the cement in the form of a gel. However, the silica fume present in the aggregates causes the accumulation of an alkaline silica gel in certain places that become potential expansion points [28]. The aim of this research is to study the effect of industrial waste used as a pozzolanic addition on the alkali aggregate reaction in mortars incorporating crushed glass.

\section{EXPERIMENTAL}

Portland cement CEM I $42.5 \mathrm{R}$, crushed waste glass, glass powder, and metakaolin were used for the tests. The physical and mechanical properties of the materials used are given in Table 1 . Table 2 presents the chemical compositions of the cement, glass powder and metakaolin. The pozzolanic activity of the glass powder $\left(560 \mathrm{mg} \cdot \mathrm{g}^{-1}\right)$ was found to be lower compared to the activity of metakaolin $\left(927 \mathrm{mg} \cdot \mathrm{g}^{-1}\right)$.

Sand of a $0 / 4$ fraction, particle density of $2488 \mathrm{~kg} \cdot \mathrm{m}^{-3}$ and a bulk density of $1643 \mathrm{~kg} \cdot \mathrm{m}^{-3}$ was used for the tests. Glass powder of a $0 / 4$ fraction was used.

Table 1. Properties of the cement, glass powder and metakaolin.

\begin{tabular}{lccc}
\hline \multicolumn{1}{c}{ Properties } & CEM I 42.5 R & Glass powder & Metakaolin \\
\hline Specific surface area $\left(\mathrm{cm}^{2} \cdot \mathrm{g}^{-1}\right)$ & 3700 & 2514 & 7036 \\
Particle density $\left(\mathrm{kg} \cdot \mathrm{m}^{-3}\right)$ & 3200 & 2500 & 2147 \\
Bulk density $\left(\mathrm{kg} \cdot \mathrm{m}^{-3}\right)$ & 1200 & 850 & 600 \\
Pozzolanic activity $\left(\mathrm{mg} \cdot \mathrm{g}^{-1}\right)$ & - & 560 & 927 \\
Standard consistency paste $(\%)$ & 25.4 & - & - \\
Initial setting time (min) & 140 & - & - \\
Final setting time (min) & 190 & - & - \\
Compressive strength after 7 days (MPa) & 28.9 & - & - \\
Compressive strength after 28 days (MPa) & 54.6 & - & - \\
\hline
\end{tabular}

Table 2. Chemical composition of the cement, glass powder and metakaolin.

\begin{tabular}{|c|c|c|c|c|c|c|c|c|c|}
\hline \multicolumn{10}{|c|}{ Chemical composition of cement $(\%)$} \\
\hline$\overline{\mathrm{SiO}_{2}}$ & $\mathrm{Al}_{2} \mathrm{O}_{3}$ & $\mathrm{Fe}_{2} \mathrm{O}_{3}$ & $\mathrm{CaO}$ & $\mathrm{K}_{2} \mathrm{O}$ & $\mathrm{SO}_{3}$ & $\mathrm{Na}_{2} \mathrm{O}$ & $\mathrm{TiO}_{2}$ & $\mathrm{MgO}$ & Other \\
\hline 20.76 & 6.12 & 3.37 & 63.50 & 1.00 & 0.8 & 0.3 & - & - & 4.45 \\
\hline \multicolumn{10}{|c|}{ Chemical composition of glass powder (\%) } \\
\hline$\overline{68.15}$ & 12.18 & 1.30 & 3.95 & 2.80 & - & 0.75 & 0.20 & 0.90 & 9.77 \\
\hline \multicolumn{10}{|c|}{ Chemical composition of metakaolin (\%) } \\
\hline$\overline{50.6}$ & 34.0 & 0.74 & 2.49 & 0.7 & 0.07 & 10.1 & 0.37 & 0.59 & 0.34 \\
\hline
\end{tabular}


The effect of a pozzolanic by-product containing glass powder and metakaolin on the properties and AAR resistance of mortar ...

Table 3. Mixing proportion of mortar specimens.

\begin{tabular}{lcccccc}
\hline Specimen marking by composition & MK0 & MK5 & MK10 & MK15 & MK20 & MK25 \\
\hline Metakaolin content (\%) (by weight of cement) & 0 & 5 & 10 & 15 & 20 & 25 \\
Glass powder content (\%) (by weight of cement) & 5 & 5 & 5 & 5 & 5 & 5 \\
Crushed glass content (\%) (by weight of sand) & 25 & 25 & 25 & 25 & 25 & 25 \\
Cement (\%) & 25.55 & 24.2 & 22.86 & 21.51 & 20.17 & 18.82 \\
Sand fraction (\%) & 45.45 & 45.45 & 45.45 & 45.45 & 45.45 & 45.45 \\
Water (\%) & 12.48 & 12.48 & 12.48 & 12.48 & 12.48 & 12.48 \\
Metakaolin (\%) & 0 & 1.35 & 2.69 & 4.04 & 5.38 & 6.73 \\
Glass powder (\%) & 1.35 & 1.35 & 1.35 & 1.35 & 1.35 & 1.35 \\
Crushed glass (\%) & 15.15 & 15.15 & 15.15 & 15.15 & 15.15 & 15.15 \\
5\% by weight of cement & 0.02 & 0.02 & 0.02 & 0.02 & 0.02 & 0.02 \\
W/B & 0.47 & 0.47 & 0.47 & 0.47 & 0.47 & 0.47 \\
\hline
\end{tabular}

The compositions of the specimens moulded from the cement mortar are presented in Table 3. The specimens were moulded from a concrete mix where a certain portion of cement was replaced with the glass powder and metakaolin. $25 \%$ of the sand was replaced with crushed glass powder. The water-to-binder (W/B) ratio of 0.47 was kept constant for all the specimens.

The cement mortar was mixed mechanically using a laboratory mortar mixer. The mixing time was 240 seconds. The mixed mortar was poured into standard $40 \times 40 \times 160 \mathrm{~mm}$ moulds and cured for 24 hours. After 24 hours, the moulds were disassembled and the specimens were further cured in water at $20 \pm 1.0^{\circ} \mathrm{C}$ for 27 days.

The essential physical and mechanical properties of the mortars were determined according to the applicable standards. The density of the specimens was determined according to the requirements of EN 772-13, the compressive strength was determined according to EN 196-1.

A SmartLab (Rigaku) diffractometer was used to determine the phase composition of the cement mortar specimens. The X-ray diffraction patterns were recorded in an angular range of $5-75^{\circ}(2 \theta)$, a detector step $0.02^{\circ}$, a detector movement speed of $1^{\circ}$ per minute. The Database of Crystal Structures PDF- 4+ (2016) was used for the automated quantitative analysis.

The microstructure of the cement mortar, glass powder and metakaolin was determined by means of scanning electron microscopy (SEM). Tests were made using a SEM JEOL 7600 device. The ASR resistance of the concrete specimens was tested according to the Rilem AAR-2 modified methodology. The Rilem AAR-2 test method is used to evaluate the potential alkali reactivity of aggregates when the tested specimens are kept in a $1 \mathrm{M} \mathrm{NaOH}$ solution at $80{ }^{\circ} \mathrm{C}$ for 56 days and their expansion is regularly measured.

The cement mortar was mixed mechanically using a laboratory mortar mixer. The mixing time was 240 seconds. The mixed mortar was poured into standard $40 \times 40 \times 160 \mathrm{~mm}$ moulds and cured for 24 hours. After 24 hours, the moulds were disassembled and the specimens were further cured in water at $20 \pm 1.0^{\circ} \mathrm{C}$ for 27 days.
The essential physical and mechanical properties of the mortars were determined according to the applicable standards. The density of the specimens was determined according to the requirements of EN 772-13, the compressive strength was determined according to EN 196-1.

A SmartLab (Rigaku) diffractometer was used to determine the phase composition of the cement mortar specimens. The X-ray diffraction patterns were recorded in an angular range of $5-75^{\circ}(2 \theta)$, a detector step $0.02^{\circ}$, a detector movement speed of $1^{\circ}$ per minute. The Database of Crystal Structures PDF- 4+ (2016) was used for the automated quantitative analysis.

The microstructure of the cement mortar, glass powder and metakaolin was determined by means of scanning electron microscopy (SEM). Tests were made using a SEM JEOL 7600 device. The ASR resistance of the concrete specimens was tested according to the Rilem AAR-2 modified methodology. The Rilem AAR-2 test method is used to evaluate the potential alkali reactivity of aggregates when the tested specimens are kept in a $1 \mathrm{M} \mathrm{NaOH}$ solution at $80{ }^{\circ} \mathrm{C}$ for 56 days and their expansion is regularly measured.

\section{RESULTS AND DISCUSSION}

The analysis of the glass powder particle size distribution showed that $15.1 \mu \mathrm{m}$ was the most common particle size of the tested ground waste glass. $90 \%$ of the particles were smaller than $29 \mu \mathrm{m}, 50 \%$ were smaller than $13.85 \mu \mathrm{m}$ and $10 \%$ were smaller than $2.69 \mu \mathrm{m}$. Figure 1 presents the particle size distribution of the glass. The analysis of metakaolin particle size distribution showed that $90 \%$ of the particles were smaller than $75.79 \mu \mathrm{m}$, $50 \%$ of metakaolin particles were smaller than $5.88 \mu \mathrm{m}$ and $10 \%$ were smaller than $1.27 \mu \mathrm{m}$.

Figure 2 shows the X-ray diagrams of the glass (a) and metakaolin (b), where the curves of the amorphous silica dioxide are visible in the glass powder X-ray diagram. The X-ray diffraction (XRD) analysis of the metakaolin showed the presence of quartz, illite and microcline. 
Barkauskas K., Nagrockienė D.

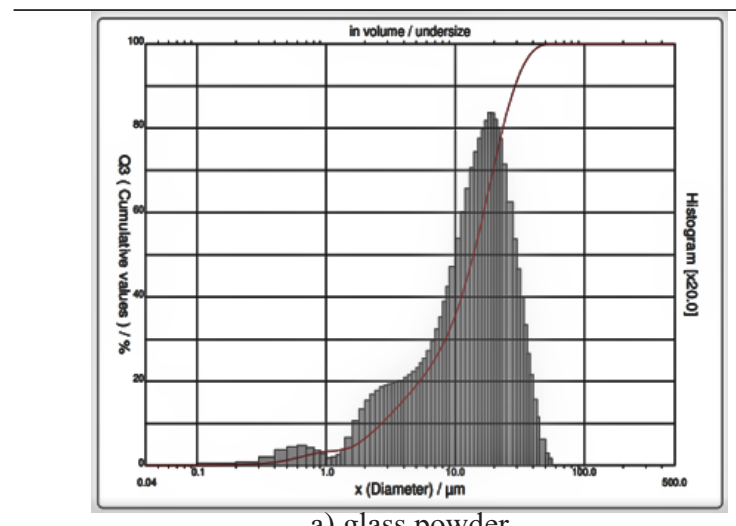

a) glass powder

Figure 1. Particle size distribution.

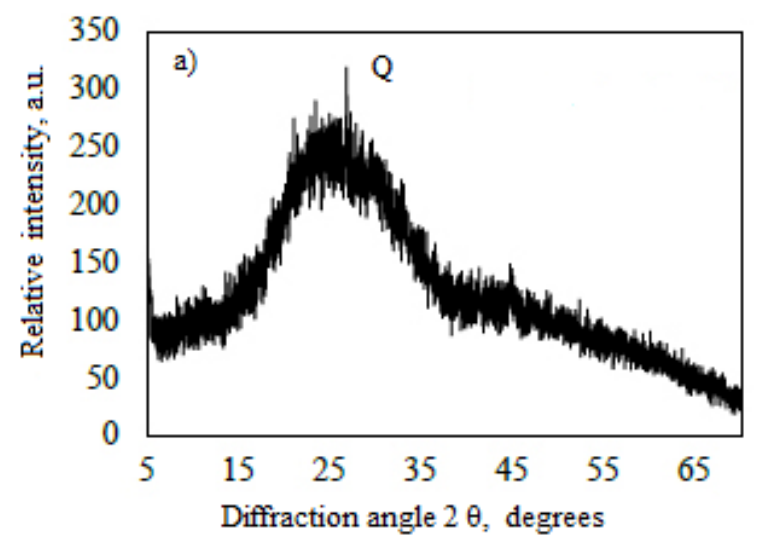

a) glass powder

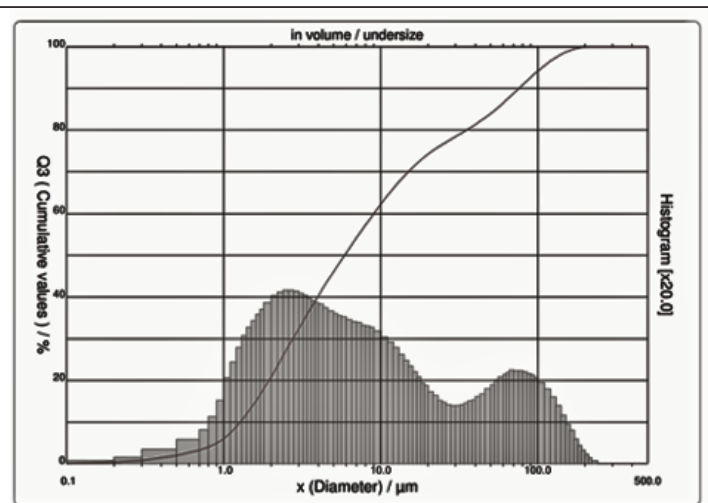

b) metakaolin

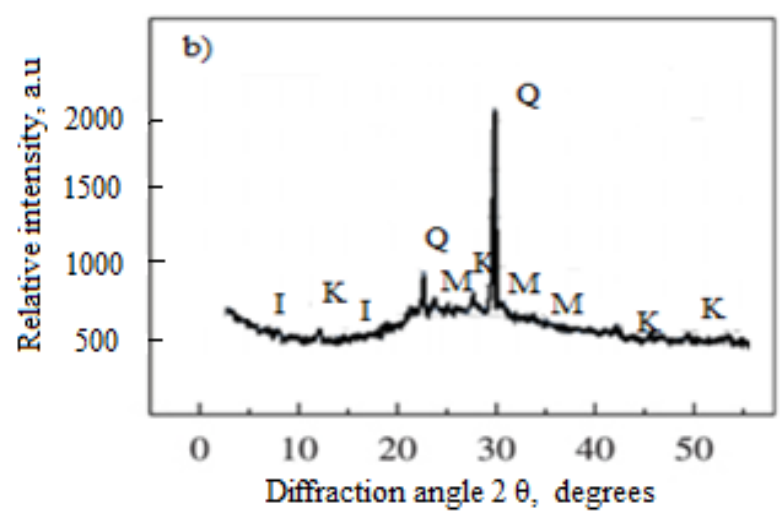

b) metakaolin

Figure 2. XRD of the a) glass powder, b) metakaolin. $\mathrm{M}$ - microcline, I - illite, $\mathrm{K}$ - kaolin, $\mathrm{Q}$ - quartz.

Figure 3 presents the results of the SEM test performed on the waste glass powder and metakaolin. According to Figure $3 \mathrm{a}$, the waste glass powder particles had an irregular shape and an average size of approx. $15 \mu \mathrm{m}$. Figure $3 \mathrm{~b}$ clearly shows metakaolin plates with an average size of $10 \mu \mathrm{m}$.

The density tests of the mortars modified with the pozzolanic waste and glass powder showed that the specimens containing $20 \%$ of the addition $(15 \% \mathrm{MK}$ and $5 \%$ GP) had the highest density of $2330 \mathrm{~kg} \cdot \mathrm{m}^{-3}$ (Figure 4). The density of the specimens tested was found to be directly related to the amount of metakaolin, i.e., a higher content of MK resulted in a higher density of the hardened mortar. The maximum difference in

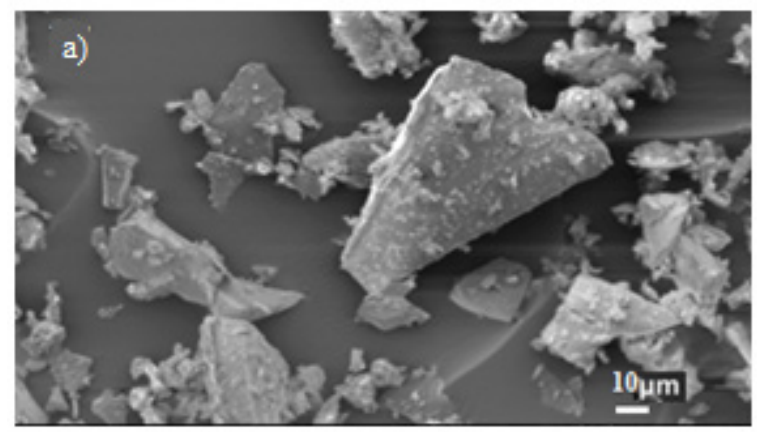

a) glass powder

Figure 3. Microstructure of the a) glass powder b) metakaolin. the density between the reference specimens and the specimens containing $15 \%$ of silica fume is $68 \mathrm{~kg} \cdot \mathrm{m}^{-3}$, i.e., $2.92 \%$. Apparently, the density values in the specimens decreased with an increase in the pozzolanic waste in the mix up to $25 \%$ and $30 \%$.

Figure 5 illustrates the effect of the pozzolanic waste on the water absorption in the mortar. Water absorption values were found to decrease with a higher metakaolin content in the specimens modified with the metakaolin and glass powder. The water absorption values decreased from $8.1 \%$ in the reference specimens to $6.8 \%$ in specimens where the cement was replaced with $15 \%$ of metakaolin. When the cement was replaced with $20 \%$ and $25 \%$ of metakaolin by weight, the water absorption

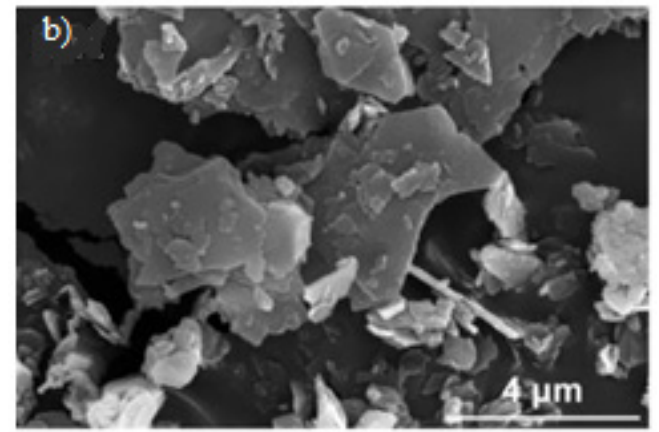

b) metakaolin 


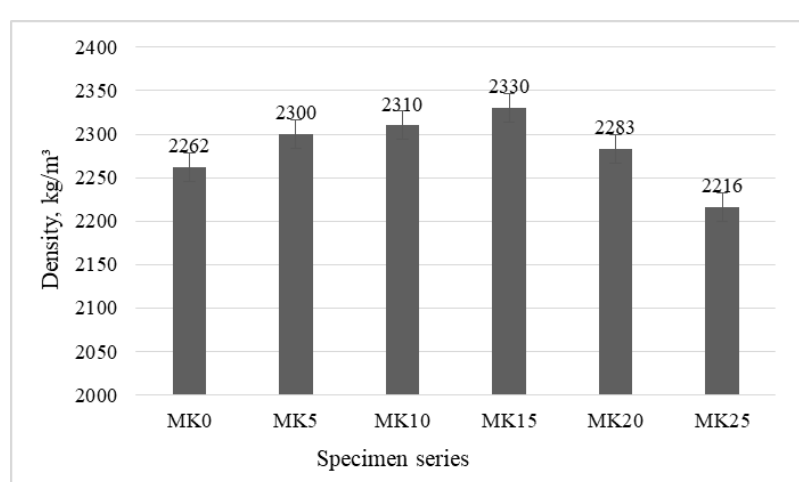

Figure 4. The effect of the pozzolanic waste on the density of the mortar specimens after 28 days of curing in water.

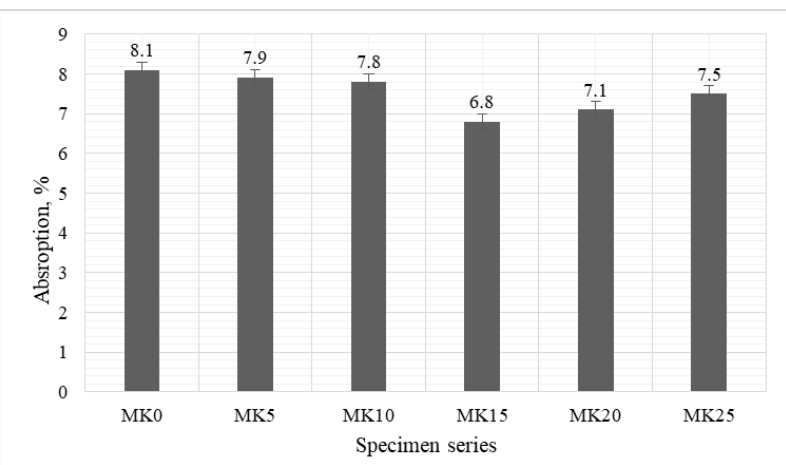

Figure 5. The effect of the pozzolanic waste on the water absorption in the cement mortar.

values increased, but did not exceed the absorption levels of the reference specimens.

Mortar bars were formed for the alkali aggregate reaction tests according to the Rilem AAR-2 methodology. Figure 6 illustrates the expansion of the specimens made of the cement CEM I 42.5 R conditioned in a $1 \mathrm{M} \mathrm{NaOH}$ solution of $80^{\circ} \mathrm{C}$ for 56 days. After 56 days of conditioning in the $1 \mathrm{M} \mathrm{NaOH}$ solution at $80^{\circ} \mathrm{C}$, the expansion of the reference specimens and specimens containing $10 \%$ of $\mathrm{MK}$ exceeded $0.1 \%$. The highest expansion of $0.26 \%$ was observed in the specimens containing $25 \%$ of crushed glass and a combined addition of $5 \% \mathrm{MK}$ and $5 \%$ of glass powder. The lowest expansion values of $0.02 \%$ were recorded in specimens

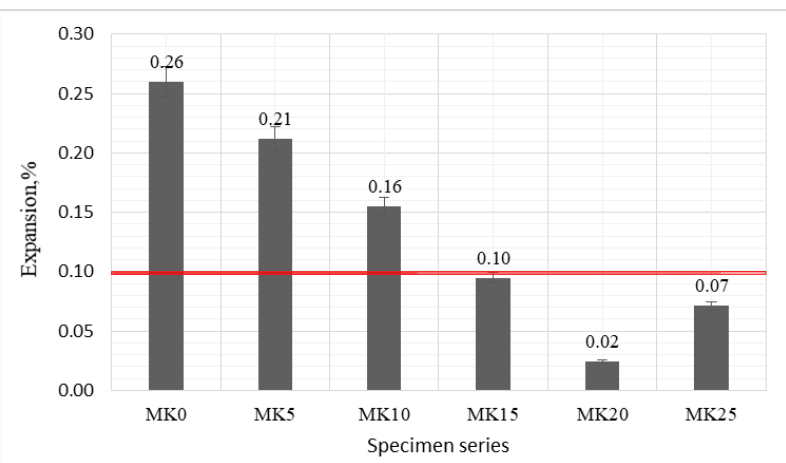

Figure 6. Expansion values of the mortar specimens made of CEM I 42.5 cement and modified with different amounts of pozzolanic waste after 56 days of conditioning at $80^{\circ} \mathrm{C}$ in a $1 \mathrm{M}$ $\mathrm{NaOH}$ solution. containing $25 \%$ of crushed glass and a combined addition of $20 \% \mathrm{MK}$ and $5 \%$ of glass powder. The expansion diagram shows that the expansion of the specimens gradually decreases when the content of metakaolin replacing the cement by weight increases from $5 \%$ to $25 \%$. It can be stated that that the expansion of the specimens incorporating crushed glass does not exceed $0.1 \%$ when the specimens are modified with pozzolanic waste (5\% GP and $15 \%-25 \% \mathrm{MK}$ ) replacing $20 \%$ to $30 \%$ of the cement by weight. Such mortars can be used in unfavourable environments, where alkali aggregate reactions can occur.

Figure 7 illustrates the flexural strength values after 56 days of expansion in an alkaline environment. The flexural strength of the mortar specimens is influenced by the expansion in the alkaline environment. The lowest flexural strength values were observed in specimens experiencing the highest expansion levels. However, after the AAR tests, the flexural strength increased in all the specimens compared to the reference specimen cured in water for 28 days. The biggest difference in the flexural strength values was observed in specimens modified with $20 \%$ MK and $5 \%$ GP. The flexural strength value increased $48.9 \%$ from $5.4 \mathrm{MPa}$ to $9.1 \mathrm{MPa}$. The flexural strength after 56 days increased due to the formation of secondary hydration products that strengthened the microstructure of the specimens.

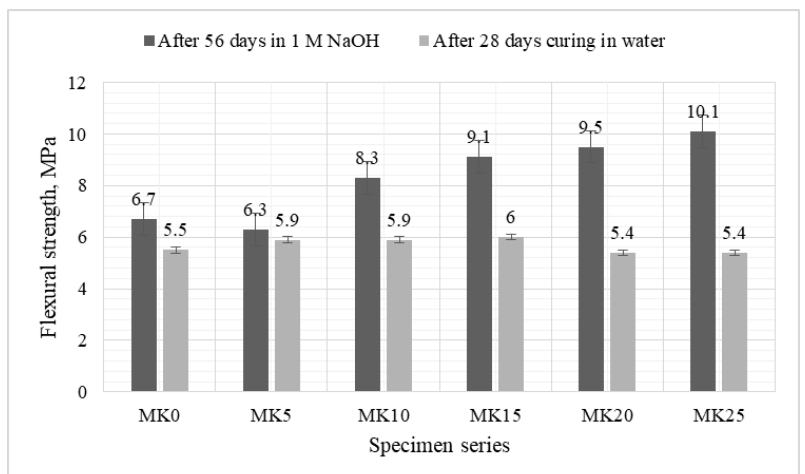

Figure 7. The effect of the pozzolanic waste on the flexural strength of the cement-based mortar.

The physical and mechanical tests of the mortars after 56 days of conditioning in the $1 \mathrm{M} \mathrm{NaOH}$ solution at $80{ }^{\circ} \mathrm{C}$ showed that the least negative AAR effect was observed in the mortar specimen modified with $25 \%$ of pozzolanic waste (5\% GP and $20 \% \mathrm{MK})$.

The compressive strength was tested after conditioning the mortar specimens in the $1 \mathrm{M} \mathrm{NaOH}$ solution at $80{ }^{\circ} \mathrm{C}$ for 56 days. The results of the tests are presented in Figure 8. The compressive strength of hardened specimens increased after the alkali aggregate reaction. The highest increase of $103 \%$ in the compressive strength, from $20.3 \mathrm{MPa}$ to $49.8 \mathrm{MPa}$, was observed in the specimens where the cement was replaced with a combined pozzolanic addition by weight ( $5 \%$ GP and $20 \% \mathrm{MK}$ ). The lowest change of $53 \%$ in 


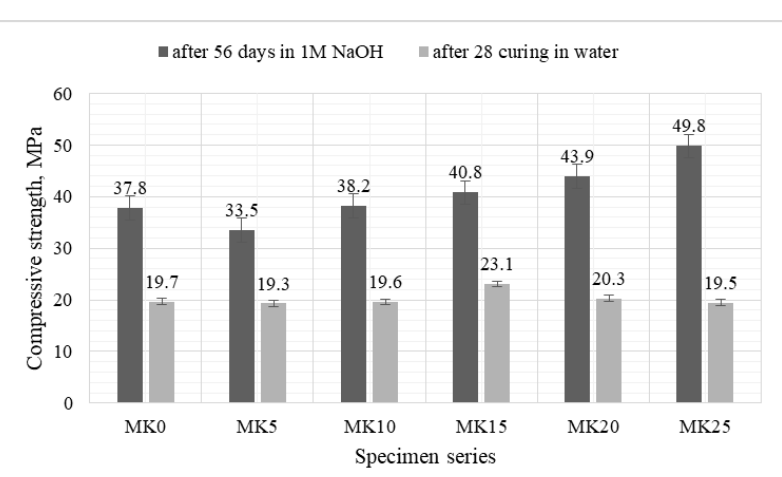

Figure 8 . The effect of the pozzolanic waste on the compressive strength of the cement-based mortar.

the compressive strength was observed in the reference specimens. The compressive strength of the reference specimens increased from 19.3 MPa to $33.5 \mathrm{MPa}$.

According to the test results of the physical and mechanical properties and expansion tests, MK20 containing $30 \%$ of pozzolanic waste (5\% GP and $25 \%$ MK) added by weight of cement was the most effective composition to modify the mortar specimens containing $25 \%$ crushed powder.

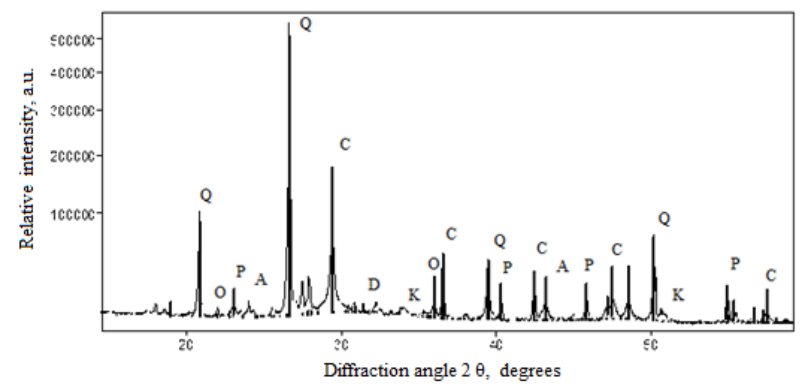

a) reference
An X-ray diffraction analysis was performed to investigate the effect of pozzolanic waste on the resistance of the mortar to the alkali aggregate reaction. Figure 9 illustrates the mineral structure of the reference mortar containing $5 \%$ of crushed glass (9a) and the cement-based mortar (9b) containing the $25 \%$ threshold quantity of pozzolanic waste (5\% GP and $20 \% \mathrm{MK}$ ) added by weight of cement. The mineral structure of the reference specimen containing $5 \%$ of crushed glass and the specimen containing $25 \%$ of pozzolanic waste is similar, but the levels of minerals present is different. The reference mortar contains $63 \%$ of quartz $\left(\mathrm{SiO}_{2}\right), 18 \%$ of calcium carbonate $\left(\mathrm{CaCO}_{3}\right)$, and $0.1 \%$ of anorthite $\left(\mathrm{CaAl}_{2} \mathrm{Si}_{2} \mathrm{O}_{8}\right), 4 \%$ of orthoclase $\left(\mathrm{K}\left(\mathrm{AlSi}_{3}\right) \mathrm{O}_{8}\right), 1.9 \%$ of portlandite $\mathrm{CaOH}_{2}, 12 \%$ of dolomite $\left(\mathrm{CaMg}\left(\mathrm{CO}_{3}\right)_{2}\right.$, and $2 \%$ of katoite $\mathrm{Ca}_{3} \mathrm{Al}_{2}\left(\mathrm{SiO}_{4}\right)_{0.64}(\mathrm{OH})_{9.44}$.

The mortar containing the $25 \%$ threshold quantity of pozzolanic waste ( $5 \%$ GP and $20 \% \mathrm{MK}$ ) consists of $52 \%$ of $\left(\mathrm{SiO}_{2}\right), 17.5 \%$ of calcium carbonate $\left(\mathrm{CaCO}_{3}\right)$, $24 \%$ of orthoclase $\left(\mathrm{K}\left(\mathrm{AlSi}_{3}\right) \mathrm{O}_{8}\right), 0.3 \%$ of portlandite $\mathrm{CaOH}_{2}, 2.3 \%$ of dolomite $\left(\mathrm{CaMg}\left(\mathrm{CO}_{3}\right)_{2}\right.$, and $3.6 \%$ of katoite $\mathrm{Ca}_{3} \mathrm{Al}_{2}\left(\mathrm{SiO}_{4}\right)_{0.64}(\mathrm{OH})_{9.44}$.

The SEM image of the structure of the cementbased mortar incorporating the crushed glass without the

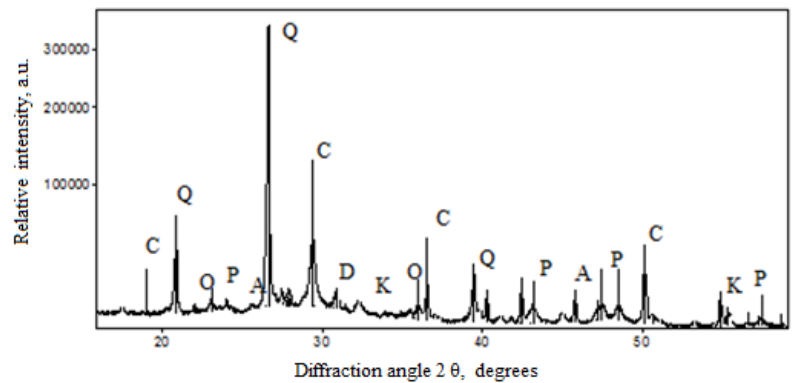

b) modified

Figure 9. XRD image of the cement-based mortar. a) reference b) modified with the $25 \%$ pozzolanic waste addition (5\% GP and $20 \%$ MK). P - Portlandite; C - Calcium Carbonate; K - Katoite; O - Orthoclase; D — Dolomite; A - Anorthite; Q Quartz.
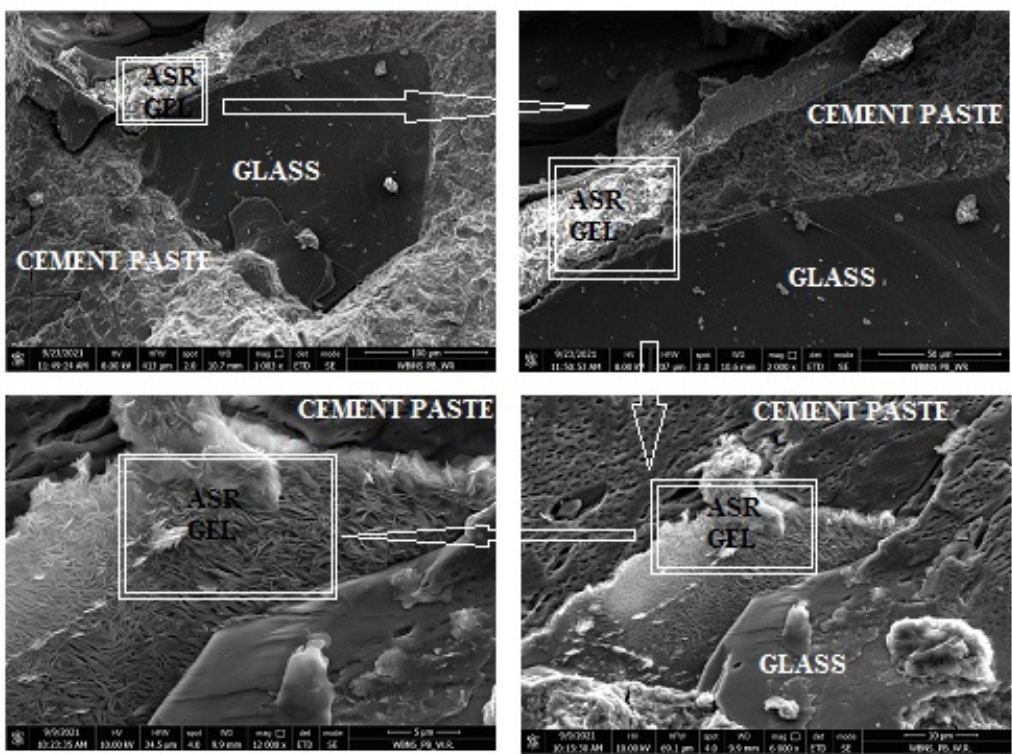

Figure 10. Microstructure of the cement-based mortar incorporating the crushed glass after expansion tests in a $1 \mathrm{M} \mathrm{NaOH}$ solution of $80{ }^{\circ} \mathrm{C}$ for 56 days. 
addition of pozzolanic waste is presented in Figure 10. Layers of alkaline gel are visible around the crushed glass aggregate in the ASR affected mortar without the pozzolanic waste. These layers of gel absorbed water and started expanding, thus causing the development of cracks in the cement matrix. A gap is also visible between the binder and the gel that had formed through the alkaline reaction of the crushed glass aggregate. The AAR-caused changes in the microstructure of the cement-based mortar reduce the density, compressive and flexural strengths of the hardened cement paste, thus causing surface cracking and scaling of the mortar during service.

Figure 11 illustrates the microstructure of the cement-based mortar incorporating crushed glass and modified with $20 \%$ of pozzolanic waste after conditioning in the $1 \mathrm{M} \mathrm{NaOH}$ solution of $80^{\circ} \mathrm{C}$ for 56 days. After the exposure of the pozzolanic waste modified cement-based mortar to an alkaline environment, the contact zone between the aggregate and the binding material is much stronger, there are very few or even no gaps compared to the mortar without the pozzolanic waste. The cracks in the cement matrix are very small and there are no visible layers of AAR products.

Glass powder contains $65.15 \%$ of $\mathrm{SiO}_{2}$, whereas metakaolin contains $50.6 \%$ of $\mathrm{SO}_{2}$, which reacts with $\mathrm{NaOH}$ and $\mathrm{KOH}$ present in the cement much faster and, thus, prevents the formation of an alkaline gel in the aggregate-binder contact zone. Therefore, the mortar modified with a compound addition of pozzolanic waste (5\% GP $+20 \% \mathrm{MK})$ added by weight of cement is resistant to an alkaline aggregate reaction.

A compound addition of pozzolanic waste made with $5 \%$ of glass powder and $20 \%$ of metakaolin can be used as a cement replacement to utilise the said waste in cement-based mortars containing crushed glass used as an aggregate instead of sand. Mortars incorporating crushed glass were found to be suitable for applications in potentially corrosive environments when modified with a $20 \%$ compound pozzolanic addition consisting of $5 \%$ ground waste glass and $15 \%$ of waste metakaolin.

\section{CONCLUSIONS}

It was found that cement-based mortars incorporating crushed glass (at $25 \%$ by weight of the cement) and modified with a compound addition consisting of $5 \%$ glass powder and $15 \%$ of metakaolin (added at $20 \%$ by weight of the cement) have better physical and mechanical properties compared to the reference specimens without pozzolanic addition. The maximum difference in the density between the reference specimens and the specimens containing $15 \%$ of silica fume is $68 \mathrm{~kg} \cdot \mathrm{m}^{-3}$, i.e., $2.92 \%$. The density values in the specimens decrease with an increase in the pozzolanic waste in the mix up to $25 \%$ and $30 \%$.

The water absorption values decreased from $8.1 \%$ in the reference specimen to $6.8 \%$ in the specimens where the cement was replaced with $15 \%$ of metakaolin. When the cement was replaced with $20 \%$ and $25 \%$ of metakaolin by weight, the water absorption values increased, but did not exceed the absorption levels of the reference specimens.

The modification to the cement-based mortar improves its physical and mechanical properties and, thus, increases the resistance to the alkali aggregate reaction. The alkali aggregate reaction tests showed that after conditioning specimens modified with $20 \%$ of compound pozzolanic addition in a $1 \mathrm{M} \mathrm{NaOH}$ solution at $80{ }^{\circ} \mathrm{C}$ for 56 days, their expansion was $0.02 \%$ and did not exceed the $0.1 \%$ limit.

The strength tests in an alkaline environment for 56 days showed an increase in the compressive and flexural strength of the mortar specimens. The biggest difference in the flexural strength values was observed in specimens modified with $20 \% \mathrm{MK}$ and $5 \% \mathrm{GP}$. The flexural strength value increased $48.9 \%$ from $5.4 \mathrm{MPa}$ to $9.1 \mathrm{MPa}$. The flexural strength increased after 56 days due to the formation of secondary hydration products that strengthened the microstructure of the specimens. The highest increase of $103 \%$ in compressive strength from $20.3 \mathrm{MPa}$ to $49.8 \mathrm{MPa}$ was observed in the
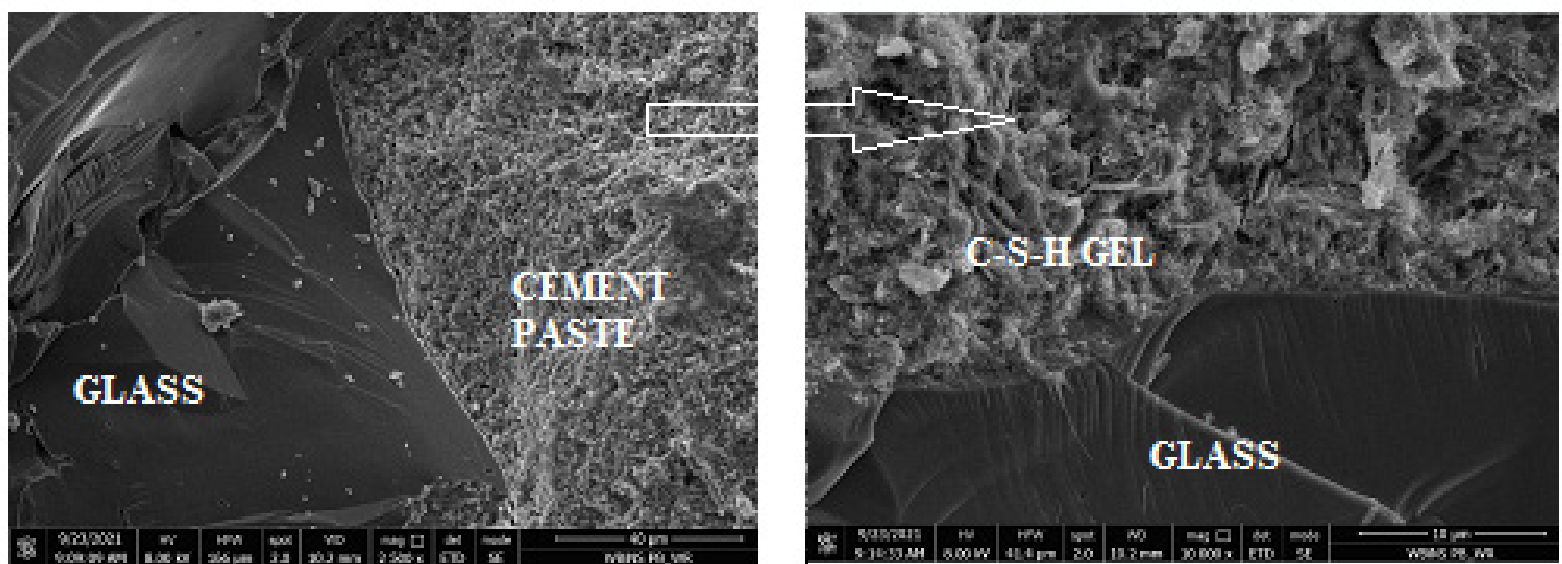

Figure 11. Microstructure of the cement-based mortar incorporating the crushed glass modified with $20 \%$ of pozzolanic waste after expansion tests in a $1 \mathrm{M} \mathrm{NaOH}$ solution of $80^{\circ} \mathrm{C}$ for 56 days. 
specimens where the cement was replaced with a combined pozzolanic addition by weight (5\% GP and $20 \% \mathrm{MK})$. The lowest change of $53 \%$ was observed in the compressive strength in the reference specimens. The compressive strength of the reference specimens increased from 19.3 MPa to 33.5 MPa.

The XRD analysis showed that, after 56 days of AAR tests, a significant amount (24\%) of additional cement hydration product orthoclase $\left(\mathrm{KSi}_{3} \mathrm{AlO}_{8}\right)$ formed in specimens containing $20 \%$ of the combined pozzolanic addition, whereas only $4 \%$ of orthoclase was found in the reference specimen containing $5 \%$ of crushed glass. A higher amount of $3.6 \%$ of katoite $\left(\mathrm{Ca}_{3} \mathrm{Al}_{2}\left(\mathrm{SiO}_{4}\right)_{0.64}(\mathrm{OH})_{9.44}\right)$ also formed. The reference specimen contained only $2 \%$ of katoite after the AAR test. The amount of portlandite $\left(\mathrm{Ca}(\mathrm{OH})_{2}\right)$ decreased from $1.9 \%$ in the reference specimens to $0.3 \%$ in the specimens modified with the pozzolanic waste. The decrease in the portlandite content indicates the formation of secondary hydration products that make the microstructure of the hardened mortar more compact which increase its density, flexural and compressive strength and AAR resistance.

The results of the conducted tests lead to the conclusion that a compound addition of pozzolanic waste consisting of $5 \%$ of glass powder and $20 \%$ of metakaolin can be used to reduce the cement content and utilise waste in cement-based mortars. It can be stated that that the expansion of specimens incorporating crushed glass does not exceed $0.1 \%$ when the specimens are modified with pozzolanic waste (5\% GP and $15 \%-25 \% \mathrm{MK}$ ) replacing $20 \%$ to $30 \%$ of the cement by weight. Such mortars can be used in unfavourable environment where alkali aggregate reactions can occur.

\section{REFERENCES}

1. Siddique R., Kahn M. I. (2011). Supplementary Cementing Materials. Berlin Heidelberg Springer-Verlag, p. 288. Doi: 10.1007/978-3-642-17866-5

2. Worrell E., Price L., Martin N., Hendriks C., Meida L.O. (2001): Carbon dioxide emissions from the global cement industry. Annual Review of Energy and the Environment, 26, 303-329. doi: 10.1146/annurev.energy.26.1.303

3. Supit S. W. M., Rumbayan R., Ticoalu A. (2017): Mechanical properties of cement concrete composites containing nano-metakaolin. AIP Conference Proceedings, 1903, 050001, 1-6. doi:10.1063/1.5011540

4. Bakera A. T., Alexander M. G. (2019): Use of Metakaolin As Supplementary Cementitious Material in Concrete, With Focus on Durability Properties. RILEM Tech Letters, 4, 89-102. doi:10.21809/rilemtechlett.2019.94

5. Abdelli H.E., Mokrani L., Kennouche S., De Aguiar J.B. (2020): Utilization of waste glass in the improvement of concrete performance: A mini review. Waste Management and Research, 38(11), 1204-1213. doi:10.1177/0734242X20941090
6. El-Diadamony H., Amer A., M. Sokkary T., El-Hoseny S. (2018): Hydration and characteristics of metakaolin pozzolanic cement pastes. HBRC Journal, 14(2), 150-158. doi: 10.1016/j.hbrcj.2015.05.005

7. Zhang S., Zhou Y., Sun J., Han F. (2021). Effect of Ultrafine Metakaolin on the Properties of Mortar and Concrete. Crystals, 11, 665. doi: 10.3390/cryst11060665

8. Santos B. S., Albuqueeque,D. M., Ribeiro D.V. (2021): Effect of the addition of metakaolin on the carbonation of Portland cement concretes. Revista IBRACON de Estruturas e Materiais, 13(1), 1-18. doi:10.1590/S198341952020000100002

9. Rajabipour F. M., Gregor H. F. (2010): Investigating the Alkali Silica Reaction of Recycled Glass Aggregates in Concrete Materials. Journal of Materials in Civil Engineering, 22(12), 1201-1208.doi:10.1061/(ASCE) MT.1943-5533.0000126

10. Ke G., Li W., Li R., Li Y., Wang G. (2018) : Mitigation Effect of Waste Glass Powders on Alkali-Silica Reaction (ASR) Expansion in Cementitious Composite. International Journal of Concrete Structures and Materials, 12(1), 1-14. doi:10.1186/s40069-018-0299-7

11. Afshinnia K., Rangaraju P. R. (2015): Mitigating alkalisilica reaction in concrete: effectiveness of ground glass powder from recycled glass. Transportation Research Record, 2508(1), 65-72. doi:10.3141/2508-08

12. Liu S., Wang S., Tang W., Hu N., Wei J. (2015): Inhibitory Effect of Waste Glass Powder on ASR Expansion Induced by Waste Glass Aggregate. Materials, 8(10), 6849-6862. doi:10.3390/ma8105344

13. Devaraj R., Jordan J., Gerber C., Olofinjana A. (2021): Exploring the Effects of the Substitution of Freshly Mined Sands with Recycled Crushed Glass on the Properties of Concrete. Applied Sciences, 11(8), 3318. doi:10.3390/ app11083318

14. Lopes R. K., Piovesan J. C., Tutikian B. F., Grondona A. (2021): Partial replacement of Portland cement with industrial glass waste in mortars. Revista IBRACON de Estruturas e Materiais, 14(2), e14214, 1-12. doi:10.1590/ S1983-41952021000200014

15. Guo S., Dai Q., Sun X., Xiao X., Si R., Jiaqing Wang J. (2018): Reduced alkali-silica reaction damage in recycled glass mortar samples with supplementary cementitious materials. Journal of Cleaner Production, 172, 3621-3633. doi:10.1016/j.jclepro.2017.11.119.

16. Keren Z. (2016): Pozzolanic reaction of glass powder and its role in controlling alkali-silica reaction. Cement and Concrete Composites, 67, 30-38. doi:10.1016/j. cemconcomp.2015.12.008

17. Thankam G. L., Renganathan T. N. (2020): Ideal supplementary cementing material - Metakaolin: A review. International Review of Applied Sciences and Engineering, 11(1), 58-65. https://akjournals.com/view/ journals/1848/11/1/article-p58.xml

18. Ding J. T., Li Z. J. (2002): Effects of metakaolin and silica fume on properties of concrete. ACI Materials Journal, 99 (4), 393-398.

19. Radonjanin V. M., Marinkovic M., Ali, S. M. (2013): Green recycled aggregate concrete. Construction and Building Materials, 47, 1503-1511. doi: 10.1016/j. conbuildmat.2013.06.076

20. Ouyang D., Xu W., Y Lo T., Sham J. (2011): Increasing mortar strength with the use of activated kaolin by-products from paper industry. Construction and Building Materials, 
25, 1537-1545. doi: 10.1016/j.conbuildmat.2010.08.012

21. Pillay D. O., Awoyera O., Rondon P., Echeverría C, John A. K. (2020). A Review of the Engineering Properties of Metakaolin Based Concrete: Towards Combatting Chloride Attack in Coastal/ Marine Structures. Advances in Civil Engineering. doi: 10.1155/2020/8880974

22. Weng T. L., Lin W. T., Cheng A. (2013). Effect of Metakaolin on Strength and Efflorescence Quantity of Cement-Based Composites. The Scientific World Journal. Doi: 10.1155/2013/606524

23. Zhenguo S., Bin Ma B., Lothenbach B. (2021): Effect of $\mathrm{Al}$ on the formation and structure of alkali-silica reaction products. Cement and Concrete Research, 140, 106311, doi: 10.1016/j.cemconres.2020.106311

24. Guillante P.A., Kulakowski P.K., Mancio M., Claudio M. K. (2019) : Synergistic effect of RHA and FCW in alkaliaggregate reaction mitigation. Ambiente Construido, 19, 7-20. doi: 10.1590/s1678-86212019000200306
25. Dinakar P., Sahoo P.K., Sriram G. (2013): Effect of Metakaolin Content on the Properties of High Strength Concrete. International Journal of Concrete Structures and Materials, 7, 215-223. doi: 10.1007/s40069-013-0045-0

26. Rajabipour F., Dunant E., Ideker C., Michael J. T. (2015): Alkali-silica reaction: Current understanding of the reaction mechanisms and the knowledge gaps. Cement and Concrete Research, 76, 130-146. doi: 10.1016/j. cemconres.2015.05.024

27. Broekmans M.A.T.M. (2012): Deleterious Reactions of Aggregate with Alkalis in Concrete. Reviews in Mineralogy and Geochemistry, 74(1), 279-364. doi: 10.2138/ rmg.2012.74.7

28. Thomas M. (2011): The effect of supplementary cementing materials on alkali-silica reaction: A review. Cement and Concrete Research, 41, 1224-1231. Doi: 10.1016/j. cemconres.2010.11.003 